\title{
REAL-WORLD OBSERVATIONAL STUDY REGARDING GLUCOSE CONTROL IN INSULIN TREATED DIABETES MELLITUS PATIENTS. GLUCOSE VARIABILITY PATTERNS ANALYSIS USING CONTINUOUS GLUCOSE MONITORING SYSTEM (CGMS)
}

\author{
MIHAELA SIMONA POPOVICIU ${ }^{1,2}$, COSMIN VESA $^{1,3}$, AURORA JURCA $^{3}$, CLAUDIA JURCA $^{3 *}$, \\ LOREDANA POPA $^{1}$, DANA ZAHA ${ }^{1,3}$, GABRIELA CEAVOI $^{4}$, ALEXANDRU JURCA ${ }^{3}$ \\ ${ }^{I}$ Clinical County Emergency Hospital of Oradea, Romania \\ ${ }^{2}$ University of Oradea, Faculty of Medicine and Pharmacy, Medical Department, Oradea, Romania \\ ${ }^{3}$ University of Oradea, Faculty of Medicine and Pharmacy, Department of Preclinical Disciplines, Oradea, Romania \\ ${ }^{4}$ University of Oradea, Faculty of Medicine and Pharmacy, Dental Medicine Department, Oradea, Romania \\ *corresponding author: claudiajurca70@yahoo.com
}

Manuscript received: May 2020

\begin{abstract}
In the present study there were evaluated 167 diabetes mellitus patients treated with insulin (without treatment with other oral antidiabetics or other non-insulin injectable antidiabetics) from the Clinical County Hospital of Oradea, Romania in terms of the prescribed insulin therapy (IT) regimen: long-acting (basal) insulin analogues, long-acting insulin analogues and rapidacting (prandial) insulin analogues or premixed insulin and the impact of the IT regimen on the glycaemic control determined by glycosylated haemoglobin (HbA1c). $35.11 \%$ of those with basal IT $(\mathrm{n}=92), 32.69 \%$ of those with basal and prandial IT $(\mathrm{n}=52)$ and $28.57 \%$ of those with premixed IT $(\mathrm{n}=21)$ reached a moderate glycaemic control $(\mathrm{HbA} 1 \mathrm{c}<7.5 \%)$ without any statistically significant differences $(\mathrm{p}=0.84) .12$ patients were selected by systematic sampling and evaluated for 6 - 8 days by inserting a continuous blood glucose monitoring system (CGMS) in a private practice healthcare office. It was found that in $72 \%$ of the monitoring period patients are outside the target glycaemic range of $70-150 \mathrm{mg} / \mathrm{dL}$ because of hyperglycaemic excursions, in $26 \%$ they fell within the therapeutic range and in $2 \%$ they were outside the range because of hypoglycaemic excursions. The frequency of hypoglycaemia was high, 50\%, but the majority were mild hypoglycaemias and the time spent in hypoglycaemia was extremely short. Therefore modern IT is safe in terms of the risk of hypoglycaemia but glycaemic control is rarely achieved. Hyperglycaemic excursions as demonstrated by CGMS data cannot be explained as hyperglycaemia consecutive to hypoglycaemia.
\end{abstract}

\section{Rezumat}

În studiul de față au fost evaluaţi 167 de pacienți cu diabet zaharat insulino-necesitant din cadrul Spitalului Clinic Judeţean Oradea (fără tratament cu antidiabetice orale sau alte antidiabetice injectabile non-insulinice) în ceea ce priveşte tipul de insulinoterapie (IT) folosit: analogi de insulină cu acțiune îndelungată (insulină bazală), analogi de insulină bazală și analogi de insulină cu acțiune rapidă (insulină prandială) sau insulină premixată, respectiv impactul tipului de IT asupra controlului glicemic determinat prin hemoglobina glicozilată (HbA1c). 35,11\% din cei cu IT bazală $(n=92), 32,69 \%$ din cei cu IT bazală și prandială $(n=52)$ şi $28,57 \%$ din cei cu IT premixată $(n=21)$ au atins controlul glicemic moderat $(H b A 1 c<7,5 \%)$ fără a exista diferenţe semnificative statistic $(p=0,84)$. Au fost selectaţi 12 pacienţi prin eşantionare sistematică şi monitorizaţi timp de 6 - 8 zile prin montarea unui sistem de evaluare continuă a glicemiei (CGMS) în cadrul unui cabinet privat. Se constată că, în $72 \%$ din perioada de monitorizare, pacienţii sunt în afara intervalului glicemic ţintă de $70-150 \mathrm{mg} / \mathrm{dL}$ prin excursii hiperglicemice; în $26 \%$ se încadrează în intervalul terapeutic, iar în $2 \%$ sunt în afara intervalului prin excursii hipoglicemice. Frecvenţa hipoglicemiilor a fost mare, 50\%, dar majoritatea au fost hipoglicemii uşoare, iar timpul petrecut în hipoglicemie a fost extrem de redus. Aşadar IT modernă este sigură din punct de vedere al riscului de hipoglicemie, dar controlul glicemic este rar atins. Excursiile hiperglicemice după cum demonstrează datele CGMS nu pot fi explicate ca fiind hiperglicemii reactive unor episoade hipoglicemice.

Keywords: diabetes mellitus, insulin therapy, continuous glucose monitoring

\section{Introduction}

Diabetes mellitus treatment options have widely extended since the introduction of insulin analogues in 1996, pharmacological agents that have numerous benefits and their proper utilisation can, at least theoretically, mimic the physiological action of insulin.
Widely utilised rapid-acting insulin analogues are insulin aspart, insulin lispro and insulin glulisine [18] while the most frequent used long-acting insulin analogues are represented by insulin glargine and insulin detemir. The synthesis of these analogues is achieved by modern recombinant DNA technology; 
the structure of insulin is slightly modified in order to influence the pharmacodynamics and pharmacokinetics of insulin. These modifications determined important characteristics of novel insulins such as a more rapid absorption from the subcutaneous tissue, in generally, 15 - 20 minutes for rapid-acting insulin analogues (prandial insulin) and a duration of action of up to 20 - 24 hours for long-acting insulin analogues (basal insulin) $[12,29,32]$. The inconvenience with rapidacting insulin analogues pharmacodynamics is that they act for $2-4$ hours and therefore postprandial hypoglycaemia can occur, but there are also issues regarding the pharmacodynamics of long-acting analogues, nocturnal hypoglycaemia is possible because of the inability of liver gluconeogenesis to compensate the lack of any nutrients intake during night [24]. Hypoglycaemia risk is higher with more intensive IT, which includes administration of rapid-acting insulin before every meal [4] and it is particularly important to prevent hypoglycaemia in the elderly population because of the risk of cognitive decline or falls [21, 24]. Polypharmacy should to be avoided in elderly patients, and a not so aggressive glycaemic target of $\mathrm{HbA} 1 \mathrm{c}$ of $7.5 \%$ needs to be set. On the other hand, persistent hyperglycaemia is another obstacle in achieving the goals in insulin-treated diabetes mellitus, either because of low, inadequate dose of insulin or because of an inadequate diet that includes high-refined sugars or sweetened beverages. Hyperglycaemia is without doubt associated with cardiovascular diseases and it was demonstrated that an increase of $1 \%$ of $\mathrm{HbA} 1 \mathrm{c}$ level is associated with an $18 \%$ increase of cardiovascular risk [22].

The aim of our study was to evaluate the influence of different IT regimens on the degree of glucose control in a cohort of type 2 and type 1 diabetes mellitus patients from north-western Romania. The objectives were to observe whether there is a statistically significant correlation between IT regimen and glucose control and to have a more in-depth look at glycaemic excursions using modern CGMS technique, to evaluate what type of excursions predominate, hyperglycaemic or normoglycaemic, to assess the percentage of time in range (or time spent with optimal glycaemic control), and to determine the risk of hypoglycaemia..

\section{Materials and Methods}

\section{Materials}

Our study was performed in the Diabetes mellitus Clinic from the Clinical County Emergency Hospital of Oradea, Romania and then in a private medical clinic for a subgroup of patients. The study was performed between 01.10.2019 and 31.12.2019. The flow-diagram of the study is illustrated in Figure 1.
440 patients eligible for inclusion

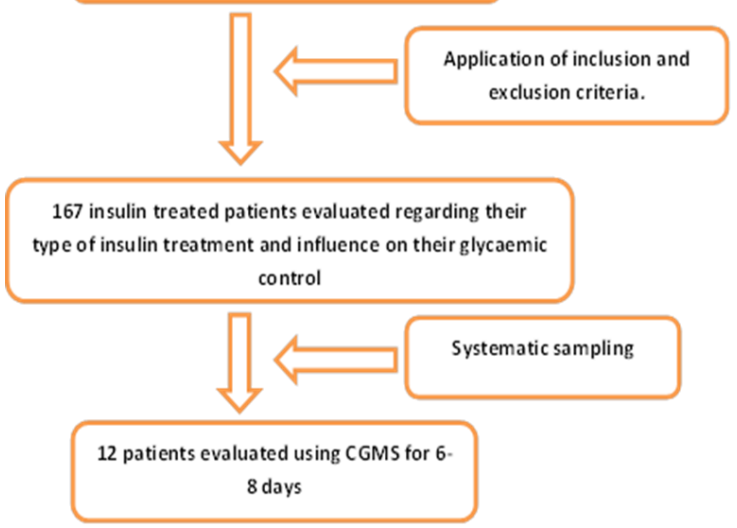

Figure 1.

The flow-diagram of the study

In the above specified interval each patient that was evaluated during one day-hospitalisation was considered for inclusion in the study. The inclusion criteria were: patients aged between 18 and 75 years old, with confirmed diabetes mellitus type 2 or type 1 treated with insulin, patients that gave their accept for inclusion in the study and signed an informed consent. The exclusion criteria were: treatment with oral antidiabetic drugs, patients that did not know their diabetes therapy. In the present study patients with oral antidiabetic drugs or non-insulin injectable therapy were excluded because the aim of the study was to determine the impact of IT alone on glucose control, as it is well known that antidiabetic drugs such as SGLT-2 inhibitors or GLP-1 agonists significantly influence glucose control, therefore the obtained $\mathrm{HbAlc}$ is a result of the combination of IT and the specific oral antidiabetic drug. 440 patients were considered for inclusion in the study, but after the inclusion and exclusion criteria were applied 167 patients remained in the study. 12 of these patients were further evaluated in a medical private clinic using a continuous glucose monitoring system (CGMS), Medtronic iPro2 ${ }^{\mathrm{TM}}$. These 12 individuals agreed to use this device for $6-8$ days in order have more information regarding their glycaemic control. The selection of the 12 patients was done in the following way: the first patient that presented on Monday during every week (12 weeks) in the above specified time interval and that fulfilled the inclusion criteria was selected for CGMS device implant in a private clinic. The duration of CGMS monitoring was of $6-8$ days. The study was done with the agreement of the hospital ethic commission and was conducted according to the principles of the World Medical Association Code of Ethics (Declaration of Helsinki, 1967).

For each of the 167 patients information was collected about age, gender, diabetes type, diabetes complications, type of insulin used. Glucose control was assessed by HbaAlc and basal glycaemia. A level of HbA1c $<7 \%$ 
was considered as an intensive glucose control, while $\mathrm{HbA} 1 \mathrm{c}<7.5 \%$ was considered a moderate glucose control. For the 12 patients that were evaluated with the CGMS, after data recording by the sensor, it was uploaded in the CareLinkiPro software, the following information was determined: average glucose, predicted HbA1c, percentage of time spent with glucose values above $150 \mathrm{mg} / \mathrm{dL}$, percentage of time spent in glucose range values between $70-150 \mathrm{mg} / \mathrm{dL}$, and below 70 $\mathrm{mg} / \mathrm{dL}$, highest, a lowest and average glucose values, standard glucose deviation, MAD\%, number of high excursions, number of low excursions, area under curve above limit and area under curve below limit. Statistical analysis

Statistical analysis was performed using Biostat software version 5.8.3.0. Chi-squared test was used for comparison of frequency and Anova test was used for comparison of mean values. A value of $p<0.05$ was considered statistically significant.

\section{Results and Discussion}

The percentage of diabetes mellitus patients that were treated with long-acting insulin analogue was $56.29 \%$, long-acting insulin and rapid-acting insulin treatment

was found in $31.14 \%$ of cases, while premixed insulin treatment was identified in $12.57 \%$ of cases (Figure 2).

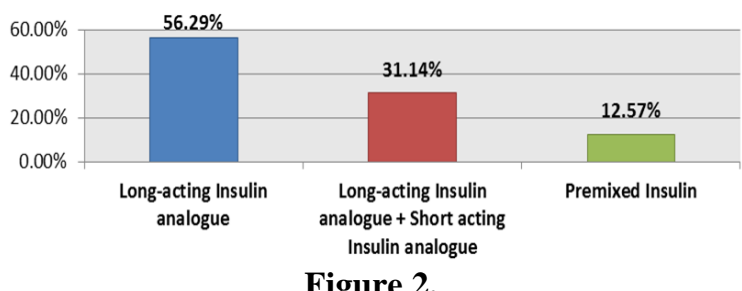

Type of IT used among the patients included in the study

The low prevalence of premixed IT regimen in our study is a favourable sign regarding the adherence to the current diabetes mellitus treatment guidelines, meaning that physicians take into account that this type of IT is associated with a higher risk of hypoglycaemia, and the titration process is considerably more difficult compared with insulin analogues [1]. The patients in the long-acting insulin analogue and short-acting insulin analogue group were statistically significant younger than patients in the other two groups (Table 1).

Table I

Parameters of the included patients according to IT type

\begin{tabular}{|l|c|c|c|c|}
\hline \multicolumn{1}{|c|}{ Parameter } & $\begin{array}{c}\text { Long-acting insulin } \\
\text { only - group I } \\
(\mathrm{n}=94)\end{array}$ & $\begin{array}{c}\text { Long-acting insulin + short } \\
\text { acting insulin - group II } \\
(\mathrm{n}=52)\end{array}$ & $\begin{array}{c}\text { Premixed } \\
\text { group III } \\
(\mathrm{n}=21)\end{array}$ & p-Value \\
\hline Age (years) & $64.35 \pm 8.13$ & $57.53 \pm 16.51$ & $63.71 \pm 9.24$ & $<0.01$ \\
\hline Sex (\% men) & 46.81 & 55.77 & 61.9 & 0.35 \\
\hline Diabetes mellitus type & & & & \\
\hline \multicolumn{1}{|c|}{ Type 2(\%) } & 100.00 & 84.62 & 100.00 & 0.28 \\
\hline Type 1 (\%) & 0.00 & 15.38 & 0.00 & \\
\hline Diabetes duration (years) & $11.32 \pm 5.93$ & $11.05 \pm 6.02$ & $11.66 \pm 5.87$ & 0.9 \\
\hline BMI (kg/m) & $33.04 \pm 6.33$ & $32.14 \pm 6.49$ & $32.36 \pm 4.50$ & 0.68 \\
\hline HbA1c (\%) & $8.18 \pm 1.85$ & $8.20 \pm 1.27$ & $8.15 \pm 1.35$ & 0.5 \\
\hline HbA1c $<7 \%$ & 21.28 & 21.15 & 19.04 & 0.86 \\
\hline HbA1c $\geq 7 \%$ & 78.72 & 78.85 & 80.96 & \\
\hline HbA1c <7.5\% & 35.11 & 32.69 & 28.57 & 0.84 \\
\hline HbA1c $\geq 7.5 \%$ & 64.89 & 67.31 & 71.43 & \\
\hline Basal glycaemia (mg/dL) & $182.18 \pm 63.62$ & $195.13 \pm 79.12$ & $195.23 \pm 70.10$ & 0.05 \\
\hline Basal glycaemia $\geq 150 \mathrm{mg} / \mathrm{dL}(\%)$ & 51.06 & 67.31 & 76.19 & 0.03 \\
\hline
\end{tabular}

This can be explained by the presence of type 1 diabetes mellitus patients, $15.38 \%$, in the second group, being a well-known fact that type 1 diabetes mellitus appears at earlier ages.

The fact that all the patients with type 1 diabetes mellitus in our study belong to the second group is again a favourable one regarding the adherence of the diabetes mellitus physicians to the guidelines. It was demonstrated that patients with type 1 diabetes mellitus need to be treated with basal and prandial insulin, not with premixed insulin because the titration process is easier with long-acting and rapid-acting insulin analogues than with premixed insulin. It can be observed that regardless of the IT type a small percent of patients achieves intensive glucose control: $21.28 \%$ in the group treated with long-acting insulin, $21.15 \%$ in the group treated with long-acting insulin analogue and rapid-acting insulin and $19.04 \%$ in the group treated with premixed insulin $(\mathrm{p}=0.86)$. A moderate glucose control was obtained in $35.11 \%$ of patients in the group treated with long-acting insulin, $32.69 \%$ in the group treated with long-acting and short-acting insulin and $28.57 \%$ in the group treated with premixed insulin $(\mathrm{p}=0.84)$ (Table 1, Figure 3 ). 
FARMACIA, 2021, Vol. 69, 2

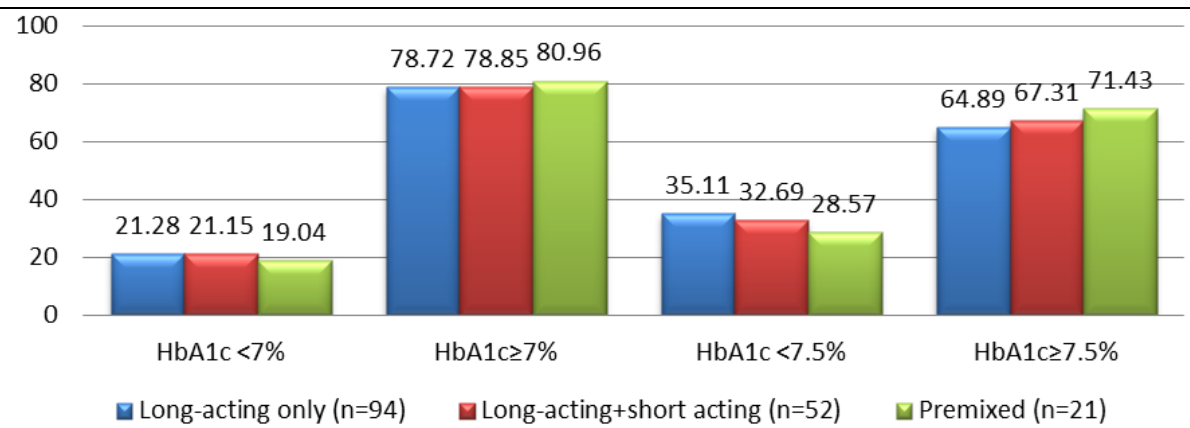

Figure 3.

Influence of IT type on glycaemic control

Therefore at least from our data no specific type of IT regimen is superior in obtaining the glucose control. Although, the results from our study may seem worrying regarding the prevalence of glycaemic control, data from literature demonstrates that in reallife studies patients rarely achieve glucose control. The Diabetes Distress and Care Registry at Tenri (DDCRT9) study, a real-life observational study performed in Japan, demonstrated that among patients with longacting insulin analogue treatment $26.6 \%$ of patients had a HbA1c $<7 \%$, among patients with premixed insulin treatment $23.9 \%$ had a $\mathrm{HbA} 1 \mathrm{c}<7 \%$, while among the patients receiving basal-bolus therapy meaning long-acting insulin analogue and rapid-acting insulin analogue before every main meal $22.9 \%$ had a HbA1c $<7 \%$ [8]. Therefore data from DDCRT9 trial is comparable with our results.

Long-acting insulin analogues used by the patients in our study were insulin glargine and insulin detemir. In our study among 146 patients with long acting insulin analogue therapy, patients from group I and II, 120 patients used insulin glargine and 26 patients used insulin detemir. These long-acting insulin analogues have a flatter pharmacodynamics profile, with a slower absorption in circulation and a significantly lower peak of action when compared with neutral protamine Hagedorn (NPH) insulin [23]. Insulin glargine was produced by replacing asparagine with glycine in position 21 of the A chain and by supplementation with two arginine residues in positions 31 and 32 of the $B$ chain [28] while insulin detemir has a unique design that consisted in adding a fatty acid in position B29 bonded to lysine and removing the terminal threonine in position 30 which determines the selfassociation of the insulin molecules into hexamers [28]. The main advantage of long-acting insulin analogues is the reduction of number of episodes and severity of hypoglycaemia. The comparison between insulin glargine and NPH insulin in a meta-analysis revealed that while there were not any statistically significant differences regarding the percent of patients that reached the glycaemic target of $\mathrm{HbAlc} \leq 7 \%$, the use of insulin glargine was associated with a decreased risk of severe hypoglycaemia by $46 \%$ and a decreased risk of severe nocturnal hypoglycaemia by $59 \%$ [34].
Regarding the type of prandial insulin used by the patients in our study the rapid analogues used were: insulin aspart, insulin lispro and insulin glulisine. These prandial insulin analogues have a pharmacokinetic profile and a pharmacodynamic profile that closer mimic the normal release of preformed insulin from the $\beta$-cell after meals, with a faster onset of insulin effect and faster offset of insulin effect when compared with the regular rapid insulin [5]. Data from metaanalysis also support the idea that while non-superior to regular insulin regarding glycaemic control, the usage of rapid-acting insulin analogues is associated with a lower risk of hypoglycaemia [5]. The findings of our study concerning hypoglycaemia risk associated with insulin treatment support the idea that insulin analogues are associated with a low severity and a low interval spent in hypoglycaemic interval; among the 12 patients evaluated using CGMS the AUC below limit was $0.175 \mathrm{mg} / \mathrm{dL} /$ day and the total time spent in hypoglycaemia was $2 \%$ of the analysed time. This finding is important considering the fact that hypoglycaemia is a risk factor for heart rhythm abnormalities in diabetes mellitus patients, a population that, as shown in literature, have already numerous cardiometabolic risk factors for atrial fibrillation such as hypertension or obesity [10, 31].

Premixed insulins are fixed component combinations of rapid regular insulin and NPH insulin or shortacting insulin analogue and intermediate-acting insulin analogue. In our study only the combination of shortacting insulin analogue and intermediate-acting insulin analogue was used by the 21 patients in group III. The short-acting component starts acting after an average time of 10 - 15 minutes after injection and the intermediate-acting component has a duration of action ranging from 10 - 14 hours [17]. Data from studies comparing the efficacy and safety of premixed insulin analogues with that of long-acting insulin analogue therapy or basal-bolus therapy revealed that premixed insulin analogues are non-inferior regarding the analysed parameters [35]. Our findings confirm this, in our study there was not a superior glycaemic control among patients treated with long-acting analogues compared with patients treated with premixed insulin. 
FARMACIA, 2021, Vol. 69, 2

In the patients that were evaluated using CGMS there can be observed a predominance of hyperglycaemic intervals during the 6 - 8 days period of monitoring. In $26 \%$ of the analysed period the patients had normal blood glucose levels, between $70-150 \mathrm{mg} / \mathrm{dL}$, this period being defined as time in range. This concept, of time in range, is an emerging one in diabetes mellitus and its gaining importance in current research, due to the increased use of CGM devices in diabetes mellitus patients. During the Advanced Technologies $\&$ Treatments for Diabetes (ATTD) Congress that took place in 2019, time in range was defined as a key CGM metric [2]. HbA1c limitations in defining good glucose control are well-known, because an adequate $\mathrm{HbA1c}$ level can be the results of an average between numerous hypoglycaemic and hyperglycaemic episodes [39]. In our study, in the subgroup of 12 patients analysed using CGMS, time in range for the patients treated with long-acting basal insulin was $19.75 \%$, while time in range for the patients treated with shortacting insulin analogues and long-acting insulin analogues was $29.25 \%$ ( $p=0.73$ ). Time in range utility has been validated in numerous studies. It was demonstrated that increasing time in range by $80 \%$ and decreasing time spent in hypoglycaemia by $40 \%$ led to markedly reduced costs of diabetes mellitus care in a period of 10 years in the US, a reduction between $6.7-9.7$ billion USD [9]. Also time in range was inversely associated with the incidence of diabetes mellitus complications, microalbuminuria, retinopathy, myocardial infarction and lower-limb amputation $[3,37]$. Therefore time in range appears to be a very good method to assess glycaemic control, but it cannot be determined without CGMS, which supports the need for more in depth analysis of patients' glycaemic control with the help of this modern devices. CGMS usage in clinical practice is essential in reducing time in hypoglycaemia, educating and motivating the patients and analysing the correlation between self-management activities in diabetes mellitus and glycaemic control [33, 38]. $72 \%$ of the evaluated time, the patients in our study were above a glycaemic target of $70-150 \mathrm{mg} / \mathrm{dL}$, while in only $2 \%$ of time they were in hypoglycaemic state (Table II, Figure 4).

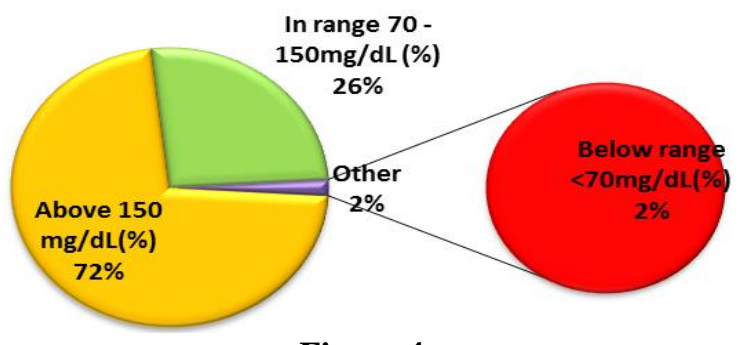

Figure 4.

Percent of time spent above, in and under glycaemic target interval among the 12 patients with CGMS device

Table II

Parameters obtained using CGMS in the 12 patients with detailed glycaemia excursion observation

\begin{tabular}{|l|c|}
\hline \multicolumn{1}{|c|}{ Parameter } & Value \\
\hline Men/Women & $66.7 \% / 33.3 \%$ \\
\hline Mean age (years) & $62.7 \pm 12.5$ \\
\hline Type 1 diabetes mellitus/Type 2 diabetes mellitus & $0 \% / 100 \%$ \\
\hline (Long-acting insulin/Long-acting + Rapid-acting Insulin) & $33.3 \% / 66.7 \%$ \\
\hline Days of excursion & 7.25 \\
\hline Average glucose (mg/dL) & 206.58 \\
\hline Above 150 mg/dL (\%) & 72 \\
\hline In range 70 - 150 mg/dL (\%) & 26 \\
\hline Below range < 70 mg/dL (\%) & 2 \\
\hline Estimated HbA1c (\%) & 8.81 \\
\hline Highest value (mg/dL) & 347.33 \\
\hline Lowest value (mg/dL) & 79.08 \\
\hline Hypoglycaemia ever detected & $50 \%$ \\
\hline Average value (mg/dL) & 206.5 \\
\hline Standard glucose deviation & 61.75 \\
\hline MAD \% & 10.57 \\
\hline Correlation & 0.85 \\
\hline Valid calibrations & 22.91 \\
\hline High excursions & 11.08 \\
\hline Low excursions & 1.16 \\
\hline AUC above limit (mg/dL/day) & 65.86 \\
\hline AUC below limit (mg/dL/day) & 0.175 \\
\hline
\end{tabular}

Concerning the relationship between the period of the day and glycaemia level it can be observed that patients mostly spend their time in hyperglycaemia during sleep, between meals and in the evening
(Figure 5). Hypoglycaemia interval represented 5\% of time spend sleeping and $5.5 \%$ of time spend after breakfast. These states of hypoglycaemia during sleep and after breakfast can be explained by the administration 
of the long-acting insulin analogue in the evening. The average value of glycaemia in the 12 patients was $206 \mathrm{mg} / \mathrm{dL}$, the estimated HbA1c was $8.81 \%$, with a predominance of high excursions (Figures 6 and 7). The fact that patients are not well controlled concerning glycaemia is also demonstrated by the high value of average Area under curve (AUC) above limit with a value of $65 \mathrm{mg} / \mathrm{dL} /$ day while the average AUC below curve was of only $0.175 \mathrm{mg} / \mathrm{dL} / \mathrm{day}$. Hypoglycaemias were detected in $50 \%$ of the analysed persons but with the exception of one moderate episode in a patient, the other episodes were represented by mild hypoglycaemias above $50 \mathrm{mg} / \mathrm{dL}$ (Figure 8).

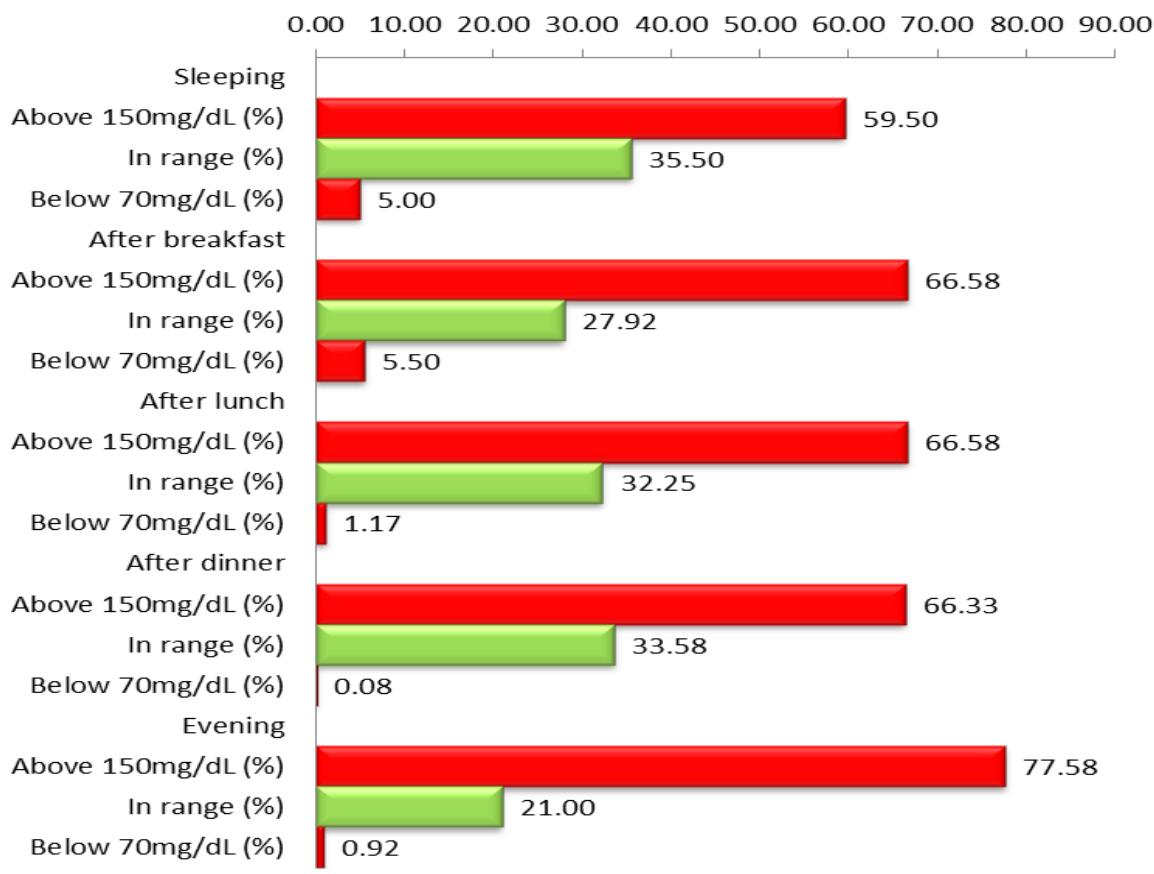

Figure 5.

Percent of time spent above, in and under glycaemic target interval among the 12 patients with CGMS device according to main meals and during sleep

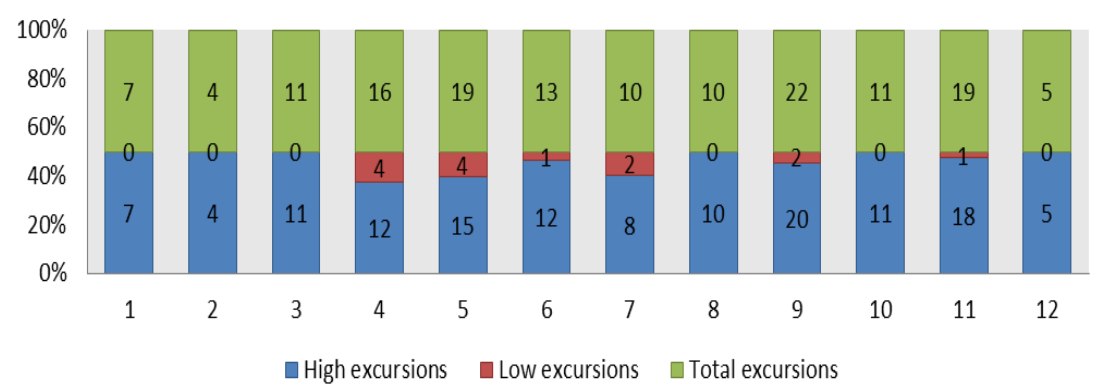

Figure 6.

Number of glycaemic excursions among the 12 patients with CGMS device

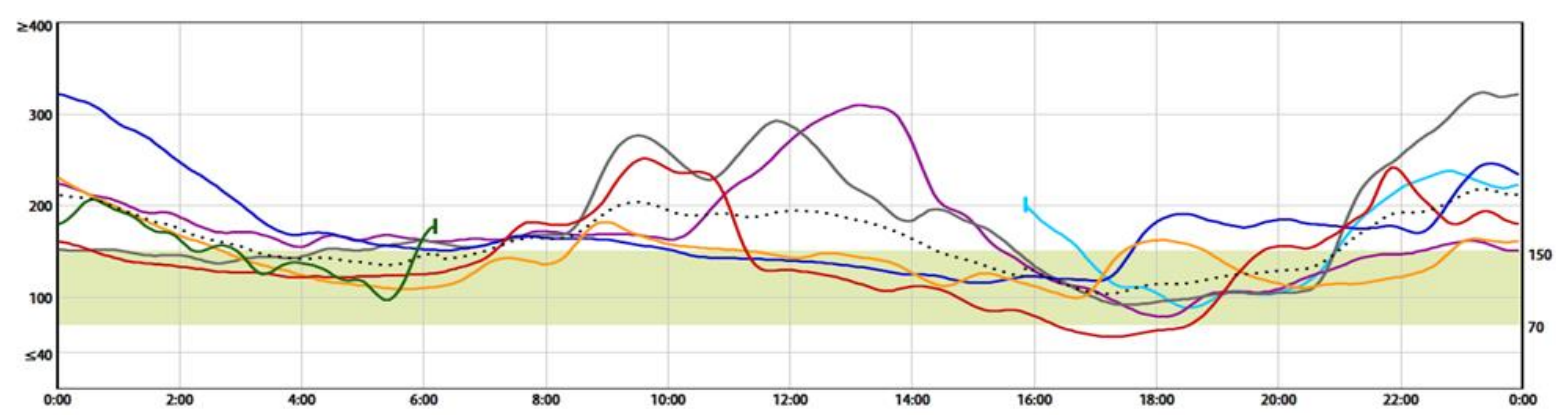

Figure 7.

Graphical illustration in a patient demonstrating frequent high excursion and one low excursion during CGMS monitoring 
FARMACIA, 2021, Vol. 69, 2

Highest $(\mathrm{mg} / \mathrm{dL}) \longrightarrow$ Average $(\mathrm{mg} / \mathrm{dL}) \rightleftharpoons$ Lowest $(\mathrm{mg} / \mathrm{dL})$

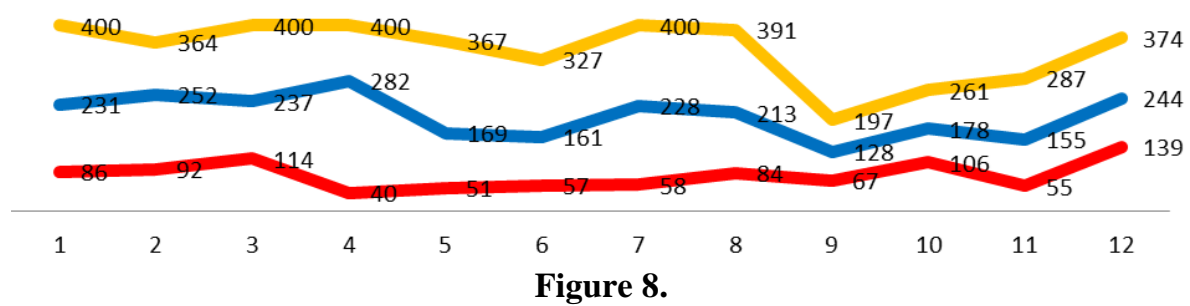

Extreme and average values during the monitoring interval among the 12 patients

It can be observed from our results that the older types of insulin such as rapid regular insulin are not any more recommended to patients, which is reflected in the low interval spent in hypoglycaemia, $2 \%$ of the total time. However if hypoglycaemia does not represent a concern of modern insulin regimens, data from CGMS demonstrates that hyperglycaemia does. The 12 patients from our study spent most of their time of CGMS monitoring in hyperglycaemic state which was reflected in their average $\mathrm{HbA} 1 \mathrm{c}$ of $8.81 \%$. One study performed in Czech Republic demonstrated that only $19.9 \%$ of the 1055 included patients had postprandial glycaemia < $140 \mathrm{mg} / \mathrm{dL}$ [40]. Postprandial hyperglycaemia represents a risk factor for cardiovascular disease; it is an expression of insulin resistance and is often accompanied by hypertriglyceridemia which contributes to the progression of atherosclerotic disease [13, 14]. In the setting of such altered glycaemic excursion and taking into account that even in countries with a very high standard of living diabetes mellitus patients do not achieve glycaemic control, patients from our study are candidates for add-on therapy with non-insulin products such as GLP-1 agonists. GLP-1 receptor agonists especially the short acting-ones such as exenatide or lixisenatide reduce post-prandial glycaemia with on average 32.4 - 116 $\mathrm{mg} / \mathrm{dL}$, therefore they could be useful in the treatment of insulin-treated patients [25]. Another effect of these non-insulin therapies is the body-weight reduction, in our study the majority of patients were obese another possibly explanation why they did not achieve the glucose level control.

The reasons why diabetes mellitus patents did not achieve the glycaemic control are multiple: delayed initiation of IT, delayed intensification of IT, lack of diabetic education implying a poor diet with high consumption of refined sugar or the disease progression itself [6]. IT itself has numerous limitations: subcutaneous administration leads to a variable speed of absorption, different concentrations from the predicted ones can appear and local factors such as blood flow can influence the subcutaneous absorption $[18,20]$.

Another important aspect in achieving serum glucose level control in diabetes mellitus patients whether under insulin therapy or not, is the quality of self-care activities performed by the patient. These self-care activities include proper nutrition, physical activity, glucose self-monitoring and adherence to treatment. Self-care management of diabetes mellitus cannot be done properly without educating the patients or the patients' family with specialized interventions, this educational interventions being universally effective in all metabolic pathology $[15,16]$. Data from literature demonstrates that nutritional interventions with improvement of diet quality by following a structured diet plan are effective in reducing HbA1c [27].

Achieving normal weight is a target with numerous beneficial effects among diabetes mellitus patients, the majority of them being either obese or overweight; the benefits of weight loss such as increased glucose control and reduced cardiovascular risk being attained by complex mechanisms such as decreased insulinresistance with concomitant reduction in glucotoxicity and lipotoxicity $[10,31]$. In our study the average BMI was $33.04 \mathrm{~kg} / \mathrm{m}^{2}$ in the first IT group, 32.14 $\mathrm{kg} / \mathrm{m}^{2}$ in the second IT group and $32.36 \mathrm{~kg} / \mathrm{m}^{2}$ in the third IT group, therefore these patients would without doubt benefit from a nutritional intervention. A metaanalysis that included a number of 124 treatment groups with a total of 17204 type 2 diabetes mellitus patients concluded that for every $\mathrm{kg}$ of lost weight there was a reduction of $\mathrm{HbA} 1 \mathrm{c}$ with $0.1 \%$ [11]. More than this, even a mild weight loss was associated with significant insulin dose reduction or discontinuation of at least one anti-diabetic medication. In a different study, weight loss of $5 \%$ of body weight was associated with a $42 \%$ of insulin dose reduction [19], a very important finding that implies than non-pharmacological intervention can significantly influence antidiabetic therapy, especially in the context of international efforts for avoiding polypharmacy [7]. As important as the improvement in diet quality for achieving glucose control is the adherence to antidiabetic treatment. In a study that evaluated the adherence to insulin therapy in different countries the percentage of insulin omission/ non-adherence was between 20 - 44\% [30]. Educational programs are the key in improving adherence to insulin therapy, one meta-analysis demonstrating that pharmacist intervention in a medical team specialized in diabetes mellitus care was associated with an increased adherence to insulin therapy and a significant HbA1c reduction [26]. 
The usefulness of our research consists in the demonstration of the fact that regardless of the IT regimen glucose control is attained in comparable percent. This finding is supported by previous research $[34,35]$ which emphasise the importance of nonpharmacological measures for diabetes mellitus patients. Although the number of patients that were analysed using CGMS was modest, this being the main limitation of our study because of the costs associated with CGMS monitoring, the importance of such analysis consisted in the determination of specific CGMS parameters such as time in range or number of hyperglycaemic excursions. Time in range had a value of $26 \%$ in our study, its low value being a marker of the poor glycaemic control of the analysed patients. Further research needs to be done to determine the factors that influence time in target and how it can be improved.

\section{Conclusions}

Insulin-treated diabetes mellitus patients rarely achieve glycaemic control, because of hyperglycaemic excursions as CGMS data demonstrates. The time in range of the patients that went through CGMS in our study was $26 \%$. There is not any correlation between the IT type, long-acting analogues, long-acting analogues and short-acting analogues or premixed insulin and achievement of glycaemic control. Using CGMS data the prevalence of ever detected hypoglycaemia was $50 \%$, but in most of the cases it was mild hypoglycaemia. Further investigations need to be done in order to identify reasons for not achieving even less stringent goals in diabetes mellitus patients. As their glycaemic excursions demonstrate, there is a high prevalence of postprandial hyperglycaemia; these patients could benefit from add-on non-insulin diabetes mellitus therapies such as GLP-1 agonists or non-pharmacological interventions such as diet quality improvement or educational programmes aimed to increase the adherence of patients to antidiabetic therapy.

\section{Conflict of interest}

The authors declare no conflict of interest.

\section{References}

1. American Diabetes Association. Standards of Medical Care in Diabetes-2020. Diabetes Care, 2020; 43(1): S1-S2

2. Battelino T, Danne T, Bergenstal RM, Amiel SA, Beck R, Biester T, Bosi E, Buckingham BA, Cefalu WT, Close KL, Cobelli C, Dassau E, DeVries JH, Donaghue KC, Dovc K, Doyle FJ $3^{\text {rd }}$, Garg S, Grunberger G, Heller S, Heinemann L, Hirsch IB, Hovorka R, Jia W, Kordonouri O, Kovatchev B, Kowalski A, Laffel L, Levine B, Mayorov A, Mathieu C, Murphy HR, Nimri R, Nørgaard K, Parkin CG, Renard E, Rodbard D, Saboo B, Schatz D, Stoner K, Urakami T, Weinzimer SA, Phillip M, Clinical Targets for Continuous Glucose
Monitoring Data Interpretation: Recommendations From the International Consensus on Time in Range. Diabetes Care, 2019; 42(8):1593-1603.

3. Beck RW, Richard M, Bergenstal RM, Riddlesworth TD, Kollman C, Li Z, Brown AS, Close KL, Validation of time in range as an outcome measure for diabetes clinical trials. Diabetes Care, 2019; 42: 400-405.

4. Buse JB, Wolffenbuttel BH, Herman WH, Hippler S, Martin SA, Jiang HH, Shenouda SK, Fahrbach JL, The durability of basal versus Lispro mix 75/25 insulin Efficacy (DURABLE) trial: comparing the durability of lispro mix 75/25 and glargine. Diabetes Care, 2011; 34: 249-255.

5. Davidson MB, Insulin analogs-is there a compelling case to use them? No!. Diabetes Care, 2014; 37(6): 1771-1774.

6. Davies M, The reality of glycaemic control in insulin treated diabetes: defining the clinical challenges. Int J Obes Relat Metab Disord., 2004; 28: 14-22.

7. Dobrică EC, Găman MA, Cozma MA, Bratu OG, Pantea Stoian A, Diaconu CC, Polypharmacy in type 2 diabetes mellitus: Insights from an internal medicine department. Medicina, 2019; 55(8): 1-10.

8. Fujita N, Yamamoto Y, Hayashino Y, Kuwata H, Okamura S, Iburi T, Furuya M, Kitatani M, Yamazaki S, Ishii H, Tsujii S, Inagaki N, Fukuhara S, Real-life glycemic control in patients with type 2 diabetes treated with insulin therapy: A prospective, longitudinal cohort study (Diabetes Distress and Care Registry at Tenri [DDCRT 9]). J Diabetes Investig., 2018; 9(2): 294-302.

9. Gabbay MAL, Rodacki M, Calliari LE, Vianna AGD, Krakauer M, Pinto MS, Reis JS, Puñales M, Miranda LG, Ramalho AL, Franco DR Pedrosa HPC, Time in range: a new parameter to evaluate blood glucose control in patients with diabetes. Diabetol Metab Syndr., 2020; 12: 1-8.

10. Gaman MA, Dobrica EC, Pascu EG, Cozma MA; Epingea ME, Gaman AM, Pantea Stoian AM, Bratu OG, Diacon C, Cardio metabolic risk factors for atrial fibrillation in type 2 diabetes mellitus: Focus on hypertension, metabolic syndrome and obesity. J Mind Med Sci., 2019; 6(1): 157-161.

11. Gummesson A, Nyman E, Knutsson M, Karpefors M, Effect of weight reduction on glycated haemoglobin in weight loss trials in patients with type 2 diabetes. Diabetes Obes Metab., 2017; 19(9): 1295-1305.

12. Heise T, Hovelmann U, Zijlstra E, Stender-Petersen K, Jacobsen JB, Haahr H, A comparison of pharmacokinetic and pharmacodynamics properties between fasteracting insulin aspart and insulin aspart in elderly subjects with type 1 diabetes mellitus. Drugs Aging., 2017; 34: 29-38

13. Hiyoshi T, Fujiwara M, Yao Z, Postprandial hyperglycemia and postprandial hypertriglyceridemia in type 2 diabetes. J Biomed Res., 2017; 33(1):1-16.

14. Iancu C, Mircea C, Petrariu F, Cioancă O, Stan C, Corciovă A, Murărașu A, Filip N, Hăncianu M, The evaluation of normo-glycemic and cyto-regenerative effects of Pelargonium species extracts. Farmacia, 2020; 68(1): 135-141.

15. Jurca C, Bembea M, Pallag A, Muresan M, Szilagyi A, Balmos A, Pop O, Jurca A, Dobjanschi L, Pharmacotherapeutical considerations in the treatment 
and management of neonatal hyperammonaemia. Farmacia, 2018; 66(2): 216-222.

16. Jurca MC, Bembea M, Iuhas OA, Kozma K, Petcheşi CD, Jurca AD, Szilágyi A, Dubau DL, Sava CN, Zaha DC, Cuc EA, Double autosomal trisomy with mosaicism 47, XY (+8)/47, XY (+21). Morphological and genetic changes of a rare case. Rom J Morphol Embryol., 2018; 59(3): 985-988.

17. Kalra S, Czupryniak L, Kilov G, Lamptey R, Kumar A, Unnikrishnan G, Boudiba A, Abid M, Akanov ZA, Latheef A, Araz M, Audehm R, Bahendeka S, Balde N, Chaudhary S, Deerochanawong C, Fasanmade O, Iraqi H, Latt TS, Mbanya JC, Rodriguez-Saldana J, Hyun KS, Latif ZA, Lushchyk M, Megallaa M, Naseri MW, Bay NQ, Ramaiya K, Randeree H, Raza SA, Shaikh K, Shrestha D, Sobngwi E, Somasundaram N, Sukor N, Tan R, Expert Opinion: Patient selection for premixed insulin formulations in diabetes care. Diabetes Ther., 2018; 9(6): 2185-2199.

18. Kroon LA, Assemi M, Carlisle BA, Diabetes Mellitus. In: Koda-Kimble MA, Young LY, Alldredge BA, Corelli RL, Guglielmo BJ, Kradjan WA, Williams BR, Applied Therapeutics: The Clinical Use of Drugs, $9^{\text {th }}$ Edition. Baltimore, MD: Lippincott, Williams and Wilkins, 2009.

19. Kumar AA, Palamaner Subash Shantha G, Kahan S, Samson RJ, Boddu ND, Cheskin LJ, Intentional weight loss and dose reductions of anti-diabetic medications-a retrospective cohort study. PLoS One, 2012; 7(2): 1-9.

20. Lindholm A, New insulins in the treatment of diabetes mellitus. Best Pract Res Clin Gastroenterol., 2002; 16: 475-492.

21. Lipska KJ, Krumholz H, Soones T, Lee SJ, Polypharmacy in the aging patient: a review of glycemic control in older adults with type 2 diabetes. JAMA, 2016; 8; 315(10): 1034-1045.

22. Luijf YM, van Bon AC, Hoekstra JB, Devries JH, Premeal injection of rapid-acting insulin reduces postprandial glycemic excursions in type 1 diabetes. Diabetes Care, 2010; 33: 2152-2155.

23. Mavrogiannaki AN, Migdalis IN, Long-acting basal insulin analogs: latest developments and clinical usefulness. Ther Adv Chronic Dis., 2012; 3(6): 249257.

24. McCoy RG, Lipska KJ, Yao X, Ross JS, Montori $\mathrm{VM}$, Shah ND, Intensive treatment and severe hypoglycemia among adults with type 2 diabetes. JAMA Intern Med., 2016; 176(7): 969-978.

25. Miñambres I, Pérez A, Is there a justification for classifying GLP-1 receptor agonists as basal and prandial?. Diabetol Metab Syndr., 2017; 9: 1-9.

26. Morello CM, Zadvorny EB, Cording MA, Suemoto RT, Skog J, Harari A, Development and clinical outcomes of pharmacist-managed diabetes care clinics. Am J Health Syst Pharm., 2006; 63(14): 1325-1331.
27. Mottalib A, Salsberg V, Mohd-Yusof BN, Mohamed W, Carolan P, Pober DM, Mitri J, Hamdy O, Effects of nutrition therapy on $\mathrm{HbA} 1 \mathrm{c}$ and cardiovascular disease risk factors in overweight and obese patients with type 2 diabetes. Nutr J., 2018; 17(1): 1-10.

28. Niswender KD, Basal insulin: physiology, pharmacology, and clinicalimplications. Postgrad Med., 2011; 123(4): 17-26.

29. Pearson SM, Trujillo JM, Conversion from insulin glargine U-100 to insulin glargine U-300 or insulin degludec and the impact on dosage requirements. Ther Adv Endocrinol Metab., 2018; 9: 113-121.

30. Peyrot M, Barnett AH, Meneghini LF, SchummDraeger PM, Factors associated with injection omission/ non-adherence in the Global Attitudes of Patients and Physicians in Insulin Therapy study. Diabetes Obes Metab., 2012; 14(12): 1081-1087.

31. Popa AR, Pusta CTJ, Vesa CM, Bungau S, Buhas CL, Sava C, Dimulescu (Nica) IA, Zaha DC, Bustea C, Prediction Models of Albumin Renal Excretion in Type 2 Diabetes Mellitus Patients. Rev Chim., 2019; 70(11): 3802-3807.

32. Roach P, Woodworth JR, Clinical pharmacokinetics and pharmacodynamics of insulin lispro mixtures. Clin Pharmacokinet., 2002; 41: 1043-1057.

33. Rodbard D, Continuous Glucose Monitoring: A review of recent studiesdemonstrating improved glycemic outcomes. Diabetes Technol Ther., 2017; 19(S3): S25-S37.

34. Rosenstock J, Dailey G, Massi-Benedetti M, Fritsche A, Lin Z, Salzman A, Reduced hypoglycemia risk with insulin glargine: a meta-analysis comparing insulin glargine with human NPH insulin in type 2 diabetes. Diabetes Care, 2005; 28(4): 950-955.

35. Sheu WH, Ji L, Lee WJ, Jabbar A, Han JH, Lew T, Efficacy and safety of premixed insulin analogs in Asian patients with type 2 diabetes: a systematic review. J Diabetes Investig., 2017; 8(4): 518-534.

36. Vashist SK, Continuous Glucose Monitoring Systems: A review. Diagnostics, 2013; 3(4): 385-412.

37. Vigersky RA, McMahon C, The relationship of hemoglobin A1C to time-in-range in patients with diabetes. Diab Technol Ther., 2019; 21: 1-5.

38. Vigersky RA, Shin J, Jiang B, Siegmund T, McMahon $\mathrm{C}$, Thomas A, The comprehensive glucose pentagon: a glucose-centric control in persons with diabetes. $J$ Diab Sci Technol., 2018; 12(1): 114-123.

39. Wright LA, Hirsch IB, Metrics beyond hemoglobin A1C in diabetes management: time in range, hypoglycemia, and other parameters. Diab Technol Ther., 2017; 19: S16-S26.

40. Žd'árská DJ, Hill M, Kvapil M, Pithová P, Brož J, Analysis of postprandial glycemia in relation to metabolic compensation and other observed parameters of outpatients with type 2 diabetes mellitus in the Czech republic. Diabetes Ther., 2018; 9(2): 665-672. 